\title{
Fire and People in Three Rural Communities in Kabylia (Algeria): Results of a Survey
}

\author{
Ouahiba Meddour-Sahar ${ }^{1}$, Raffaella Lovreglio ${ }^{2}$, Rachid Meddour ${ }^{1}$, Vittorio Leone ${ }^{3}$, \\ Arezki Derridj ${ }^{1}$ \\ ${ }^{1}$ Facultés Sciences Agronomiques et Biologiques, Department of Sciences Agronomiques B.P., Université \\ Mouloud Mammeri de Tizi-Ouzou, Tizi-Ouzou, Algeria \\ ${ }^{2}$ Department of Agriculture, University of Sassari, Sassari, Italy \\ ${ }^{3}$ Department of Crop Systems, Forestry and Environmental Sciences, University of Basilicata, Potenza, Italy \\ Email: o.sahar@yahoo.fr
}

Received September 29 $9^{\text {th }}$, 2012; revised November 11 ${ }^{\text {th }}$, 2012; accepted November $23^{\text {rd }}$, 2012

\begin{abstract}
This research was conducted to investigate about the causes of wildfires in three municipalities of the Tizi Ouzou and Bouira provinces, in Kabylia. Unknown forest fire causes account for $80 \%$ of total in Algeria, with a peak of about $99 \%$ in Kabylia, the most forested region in the country but also the most severely affected by wildfires. The three study areas exhibit a rather high forestry ratio ( $40 \%$ on average) but also a very high population density, up to 300 people per $\mathrm{km}^{2}$, living in a multitude of small hamlets, near or inside the domanial forests and exerting an enormous pressure on them. Survey was carried out on people $(\mathrm{N}=300)$ randomly selected in nine hamlets (thaddarth) through ad hoc questionnaires (134 possible replies) filled with face-to-face interviews. Factorial Correspondence Analysis was used to process data $(300 \times 134$ replies in total). Fires result mainly voluntary $(52.95 \%)$ : pastoral fires to renew pastures (11.30\%), political fires as security counter-terrorism measure (11.24\%), uncontrolled garbage burning (6.83\%). Negligent fires account for $41.79 \%$ : carelessly tossed cigarette butts (9.13\%), agricultural works (burning of cut bush, stubble burning, $7.03 \%$ ), restart of fire $(6.83 \%)$ and forest activities in the forest (6.31\%). Results depict a common core of fires due to the pressure on the domanial forests, on which traditional use of fire (pastoralism) and national security needs (counter-terrorism) dominate.
\end{abstract}

Keywords: Fire Motivations; Folk Crime; FCA; Kabylia; Pastoralism; Political Fire

\section{Introduction}

In the Mediterranean region more than 50,000 fires burn an estimated 600,000 - 800,000 hectares annually, about $1.5 \%$ of total Mediterranean woodlands (Rowell \& Moore, 2000; WWFIUCN, 2007; Cemagref, 2009). Fires are particularly abundant in the northern rim of the Mediterranean, where France, Greece, Italy, Portugal and Spain contribute with a yearly average of 49,838 fires and 471,644 burned hectares (1980-2010) (JRC, 2010).

In the southern rim fires are less abundant in terms of numbers and burned surfaces, certainly due to different socio-economic conditions (Velez, 1991), where the forest is a resource, for food, for fuel wood but mainly for grazing. Wildfires rarely naturally occur in the Mediterranean region where the only relevant natural cause of forest fires is lightning. Wildfires caused by lightning have a local character and are highly dependent on mesoscale atmospheric conditions (Petersen \& Rutledge, 1998; Garcia-Ortega et al., 2011). Apart from those possible, but minimally important causes, fires reveal a strong impact of human actions.

Mediterranean region accounts the larger proportion of human caused fires in the world (95\%) followed by South Asia (90\%), South America (85\%) and Northeast Asia (80\%) (Leone et al., 2009).

Forest fire statistics are usually compiled by processing individual wild land fire reports collected after each event by the national Forest Services, Fire Departments or other similar governmental Agencies. Assessment of cause merely reflects the opinion of the reporting officer filling the fire report; secure determinations are therefore possible only when culprits are brought to justice (Leone et al., 2009). In the list of countries of southern Mediterranean rim affected by wildfires Algeria is the first best, with more than 1300 fires per year and 39,000 hectares burned (respectively $2.34 \%$ and $6.5 \%$ of the values for the whole Mediterranean; Meddour-Sahar, 2008). Algeria has one of the longest history of fire recording, together with Cyprus (Harris, 2007), since both coming from colonial experiences.

Changes in fire occurrence are evident throughout history of colonization, confiscation of communal land and the application of modern agricultural techniques that increased the amount of arable land (Davis, 2004; Bensaid et al., 2006; FAO, 2010).

The state-owned regime for forest and pasturelands and the settlement policies imposed by the colonial period, for instance, have brought extensive conflicts between pastoral groups and the public administration (Davis, op.cit). Rural incendiarism as protest against curtailing traditional use of common lands marked the second half of XIX century (Kuhlken, 1999), when collective fines, set against communities that continued to practice fire-driven agriculture despite a ban from French colonial authorities, were met with non-compliance and an increase in malicious fire raising (Holmes, 2007). 
During the long and merciless independence war (1954-1962) fire was widely used in the scorch earth strategy by the French Army; more recently during the decade of severe political troubles of the Algerian Civil War, marked by terroristic activity, fire was among counter-terrorism measures and some forests have been destroyed to avoid giving refuge to armed groups (Bainem forest by Algiers, for example; Dridi, 2002). "The situation in this area of the Mediterranean basin is particularly alarming and should be a priority for attention of the international community” (Bariteau in: Baskaran et al., 2001).

Causes of fire in Algeria are the result of high density of rural population (ranging from 40 to over 600 inhabitants per $\mathrm{km}^{2}$ in the North Central region of the country), of growing demography, of rural exodus and countryside abandonment, of urban sprawl and increasing demand of building areas along the coast, of increasing production of home waste and of traditional forms of land use dominated by pastoralism.

In many cases the degradation of forested areas reflects a population accustomed to using forest as a free-for-all with scarce concern for forest preservation (Thirgood, 1981), and for this in strong contrast with Forestry Administration (Berchiche, n.d.). This adds to an adverse climate, with recurring droughts and long, increasingly hot summers with prolonged, severe heat waves, such as in 2012. This scenario is rather similar to other M.E.N.A. countries' with similar climatic and productive features, where rural populations maintain excessively high pressure on wooded lands, overexploiting firewood and over-grazing (FAO, 2012).

In Mediterranean countries a large fraction of the total number of forest fires remains unexplained. Algeria holds the record of unknown causes with nearly $80 \%$, followed by Tunisia, $65 \%$, Morocco, 55\% and Turkey, 48\%. The high percentage of unknown causes as in Algeria, makes it difficult the implementation of a prevention policy targeted to specific social groups or activities or behaviours (Meddour-Sahar \& Derridj, 2012). Fire causes in Algeria were object of researches in the past (Gravius, 1866; Thibault, 1866; Marc, 1916; IIA, 1933; Boudy, 1952), but more recent information about them is very scarce and dramatically reflects the extremely high incidence of unknown fires which, in some provinces in Kabylia, such as Tizi-Ouzou, is close to 99\% (Meddour-Sahar \& Derridj, 2010).

\section{Methodology}

In this paper we report the result of a survey on fire causes, carried out through interviews to people living in three fire prone areas in Kabylia (Algeria); they represent the powerless who usually have no voice and whose perspective or interpretation of the phenomenon could be different from foresters'. The 26 years time series analyzed (1985-2010), includes the "black decade" (1990-2000) of political instability which raged in the country.

\section{Study Area}

Survey was carried out in three different rural baladiyath ${ }^{1}$ (Mizrana, Ain Zaouia, Haizer), in the wilaya (province) of Tizi Ouzou and Bouira in Kabylia (Figure 1), all of them marked by more or less severe fire history.

Kabylian communities live in the forest, which provides

${ }^{*}$ Baladiah is the equivalent of municipality. them with multiple resources: foodstuffs from poaching and gathering, honey, mushrooms, fodder, firewood, timber, cork, etc. (FAO, 2012), but rural populations maintain excessively high pressure on wooded lands. Official data from the Algerian Forest Administration of the two provinces (Tizi Ouzou and Bouira) permit to measure this high pressure: from 1999 to 2009, a total of 347 offenses were officially registered, even not always sanctioned to punish non compliant behavior.

Selected baladiath are representative of different situations (littoral, North part of Djurdjura massif, South face of Djurdjura massif). Each baladiah* is formed by different douar or thaddarth (village) (21 to 28), sometimes at the edge of forested areas, in many cases inside the forest. The douar under study are mountain and forest hamlets, all of them in territories having a forestry ratio $>40 \%$, thus among the most forested ones in the region.

Forests are highly degraded by fires and by the anthropic activities (illegal cutting and constructions, overgrazing, overexploitation, pollarding for fodder etc.).

Each baladiah covers a surface roughly ranging from 5000 to 9000 hectares and is synthesized, in terms of geographic indicators, in Tables 1 and 2.

\section{Data and Methods}

Survey was conducted in a traditional method (self-administered survey; Leones, 1998) by distributing the purposely prepared questionnaires. Surveyor filled every questionnaire with a face-to-face interview, directly contacting each one of the household components. The questionnaire used simple, familiar, and unambiguous words. It is a closed-ended or fixed-item type; questions are multiple-choice with unordered response choices. The questionnaire includes 37 questions allowing 134 responses and is structured in four sections:

- Demographic information (status, gender, residence and level of education, labor condition);

- Agro-forestry activities (type of activities, type and size of husbandry, livestock feeding);

- Knowledge about fires (size, damages, causes);

- Anthropic pressure on the forest (forests' condition, occupancy, garbage burning, needs for firewood, wood cutting, constructions, forest activities).

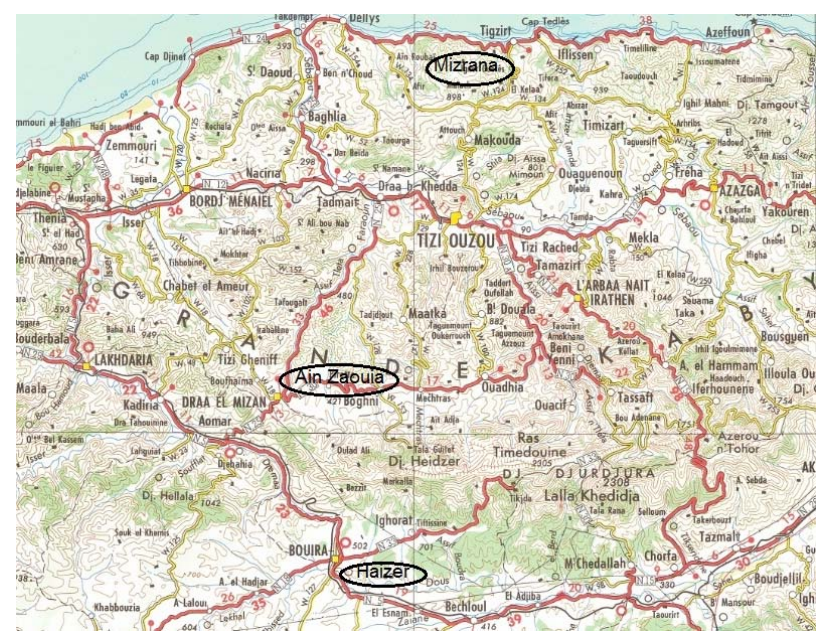

Figure 1.

Map of the study areas in Kabylia, North Central Algeria. 
Table 1

The most relevant socio-economic indicators for the study areas.

\begin{tabular}{|c|c|c|c|}
\hline Indicator/Baladiah & Mizrana & Ain Zaouïa & Haizer \\
\hline Position & Littoral & $\begin{array}{c}\text { North part of } \\
\text { Djurdjura massif }\end{array}$ & $\begin{array}{c}\text { South part of } \\
\text { Djurdjura massif }\end{array}$ \\
\hline $\begin{array}{l}\text { Geographic } \\
\text { coordinates }\end{array}$ & \multicolumn{2}{|c|}{$\begin{array}{c}36^{\circ} 20^{\prime} \text { to } 36^{\circ} 30^{\prime} \mathrm{N} \\
4^{\circ} 05^{\prime} \text { to } 4^{\circ} 07^{\prime} \mathrm{E}\end{array}$} & $\begin{array}{c}36^{\circ} 20^{\prime} \text { to } 36^{\circ} 30^{\prime} \mathrm{N} \\
3^{\circ} 55^{\prime} \text { to } 4^{\circ} 10^{\prime} \mathrm{E}\end{array}$ \\
\hline Surface (ha) & 5784 & 5677 & 8900 \\
\hline $\begin{array}{l}\text { Number of } \\
\text { villages }\end{array}$ & 28 & 29 & 21 \\
\hline Population & 9488 & 17,372 & 18,371 \\
\hline $\begin{array}{l}\text { Population density } \\
\text { per km² }\end{array}$ & 168 & 305 & 206 \\
\hline Forest land (ha) & 3595 & 2577 & 4827 \\
\hline Forestry ratio in \% & 72 & 48 & 56 \\
\hline $\begin{array}{l}\text { Agricultural land } \\
\text { (ha) }\end{array}$ & 959 & 2211 & 3628 \\
\hline $\begin{array}{l}\text { Pasture and } \\
\text { rangelands (ha) }\end{array}$ & 270 & 200 & 30 \\
\hline $\begin{array}{l}\text { Unproductive land } \\
\text { (ha) }\end{array}$ & 200 & 400 & 80 \\
\hline $\begin{array}{l}\text { Total agricultural } \\
\text { land (ha) }\end{array}$ & 5024 & 5388 & 8565 \\
\hline Sheep number & 3128 & 2834 & 1632 \\
\hline Goats number & 2395 & 1562 & 146 \\
\hline Cows number & 326 & 345 & 993 \\
\hline Total livestock & 8783 & 4741 & 2771 \\
\hline Livestock per km² & 151.80 & 83.33 & 31.13 \\
\hline Land-use & $\begin{array}{l}\text { Agro-sylvo- } \\
\text { pastoral }\end{array}$ & $\begin{array}{l}\text { Agro-sylvo- } \\
\text { pastoral }\end{array}$ & $\begin{array}{l}\text { Agro-sylvo- } \\
\text { pastoral }\end{array}$ \\
\hline
\end{tabular}

Table 2.

The most relevant forestry indicators for the study areas.

\begin{tabular}{|c|c|c|c|}
\hline Forest & $\begin{array}{c}\text { Domanial forest } \\
\text { of Mizrana }\end{array}$ & $\begin{array}{c}\text { Domanial forest } \\
\text { of Boumahni }\end{array}$ & $\begin{array}{c}\text { Domanial forest } \\
\text { of Haizer }\end{array}$ \\
\hline Forest description & Open forest & $\begin{array}{l}\text { Mediterranean } \\
\text { scrubland }\end{array}$ & $\begin{array}{l}\text { Open degraded } \\
\text { and fragmented } \\
\text { forest }\end{array}$ \\
\hline Vegetation & $\begin{array}{l}\text { Cork oak, Zeen } \\
\text { oak }\end{array}$ & $\begin{array}{l}\text { Cork oak, Wild } \\
\text { olive, Aleppo pine }\end{array}$ & $\begin{array}{l}\text { Aleppo pine, } \\
\text { Holm oak, Cedrus } \\
\text { atlantica }\end{array}$ \\
\hline Climate & $\begin{array}{c}\text { Pluviometry: } 800 \\
\text { to } 1200 \mathrm{~mm} / \mathrm{yr} \\
\text { Subhumid }\end{array}$ & $\begin{array}{l}\text { Pluviometry: } 800 \\
\text { to } 1000 \mathrm{~mm} / \mathrm{yr} \\
\text { Subhumid }\end{array}$ & $\begin{array}{l}\text { Pluviometry: } 700 \\
\text { to } 1000 \mathrm{~mm} / \mathrm{yr} \\
\text { Subhumid }\end{array}$ \\
\hline $\begin{array}{l}\text { Middle mountain } \\
\text { terrain }(400-800 \mathrm{~m})\end{array}$ & $76.31 \%$ & $53.21 \%$ & $62.95 \%$ \\
\hline $\begin{array}{l}\text { Class of dominant } \\
\text { slope }(>25 \%)\end{array}$ & $60 \%$ & $69 \%$ & $47 \%$ \\
\hline $\begin{array}{l}\text { Forest fires number } \\
\quad(1985-2010)\end{array}$ & 182 & 78 & 208 \\
\hline $\begin{array}{l}\text { Burned surface } \\
(1985-2010) \text { ha }\end{array}$ & 286 & 143 & 104 \\
\hline $\begin{array}{l}\text { Burned surface in \% } \\
\text { of forested area } \\
\text { (1985-2010) }\end{array}$ & 3.06 & 2.13 & 0.83 \\
\hline
\end{tabular}

Survey was carried out in March-May 2010 in three villages for each baladiah, where we found the support of local authorities, including the transport on the field and presentation to the village chiefs (Table 3). Surveyor (O.M.S. and her team) was always accompanied by a local key-informant, usually a member of the village committee who helped the surveyor to get in touch with the relevant villagers and above all to establish a relationship of trust.
Table 3.

Number of sampled villages.

\begin{tabular}{|c|c|c|c|c|}
\hline $\begin{array}{l}\text { Wilaya } \\
\text { (Province) }\end{array}$ & $\begin{array}{l}\text { Baladiah } \\
\text { (Town) }\end{array}$ & $\begin{array}{l}\text { Thaddarth } \\
\text { (Village) }\end{array}$ & $\begin{array}{c}\text { Total } \\
\text { household }\end{array}$ & $\begin{array}{r}\text { Sample } \\
\text { household }\end{array}$ \\
\hline \multirow{7}{*}{ Tizi Ouzou } & \multirow{4}{*}{ Mizrana } & Azroubar & 151 & 43 \\
\hline & & Ouatouba & 106 & 30 \\
\hline & & Tamazirt Ourabah & 96 & 27 \\
\hline & & $\begin{array}{c}\text { Total baladiah of } \\
\text { Mizrana }\end{array}$ & 353 & 100 \\
\hline & \multirow{4}{*}{ Ain Zaouia } & Adbagh & 29 & 18 \\
\hline & & Ait Amar Moh & 48 & 29 \\
\hline & & Igharviyen & 80 & 53 \\
\hline \multirow{6}{*}{ Bouira } & & $\begin{array}{l}\text { Total baladiah of } \\
\text { Ain Zaouia }\end{array}$ & 157 & 100 \\
\hline & \multirow{4}{*}{ Haizer } & Guentour & 190 & 56 \\
\hline & & El Mahsar & 46 & 13 \\
\hline & & Slim & 105 & 31 \\
\hline & & $\begin{array}{c}\text { Total baladiah of } \\
\text { Haizer }\end{array}$ & 341 & 100 \\
\hline & Total & & 851 & 300 \\
\hline
\end{tabular}

At first some difficulties in contacting households arose and made necessary the intervention of village leaders to explain that surveyors were not sent by the government to investigate about offences in the forest, but emphasizing that their interest was directed to protect forest against fires.

The target population for the survey consists of 100 individuals aged 15 and older of both sexes, for each baladiah. The unit of observation is a household in the selected villages. Sampling plan and size for each village is reported in Table 3. At the household level, the sample of the interviewees was large enough in size in relation to the defined target population. The three baladiah encompass a total of 78 villages; the choice of three villages for baladiah (9 villages in total) therefore gave a sampling rate of $11.53 \%$. Given the security constraints in the area (terrorism), the expected results and the specificities of the Kabylian village residents, a sample of nearly 300 individuals was decided, thus representing a sampling rate of $35.25 \%$ (300 out of 851 households). Not having the availability of lists of inhabitants, a systematic sampling on the field was then applied in agreement with village leaders, by taking a household out of three for Mizrana and Haizer, and one out of two in Ain Zaouia. Sampling was very difficult in the absence of listing, and even on the field; contact also was difficult, since some families refused to participate in the investigation or were not at home. On the contrary, an open willingness came from University students, thus explaining the relatively high percentage of them among respondents (18.7\%). A research whatever has never been carried out in those villages and their forests have no management plan.

\section{Results}

Data were processed using Sphinx plus V5 survey and statistics software (www.lesphinx-developpement.fr/).

Sample is mainly composed of male $(81.7 \%)$, rather young individuals (65.7\% under 39 years), mainly living in the forest (48.7\%) or near it (19\%). This is specific for Kabylia but not for Maghreb, since in Tunisia and Morocco the similar percentage is no more than 10\% (Colin \& Jappiot, 2001). 
Labor status is strongly characterized by unemployment (51\%), followed by employment in Government (16\%) and work in agriculture (14\%), be it self-employment or wage work; the number of retired (8\%) and students (8\%) is low. In general, all people, even in official status of unemployed or employed, work their land, as it is usual in rural societies. People under observation have a rather low education level (illiterate account for $25.3 \%$; primary and college school level for $37 \%$, secondary school for $19 \%$, University level for $18.7 \%$ ). The latter percentage, however, marks the interest for high levels of education also in small rural communities and, in addition, the relevant attractive power by University in the backcountry.

Main activities (more than 50\%) are olive growing and husbandry, followed by growing fruit trees and vegetables. Beekeeping is rather important $(14.7 \%)$ based on a reduced number of beehives (the modal value $46.7 \%$ is less than 4 beehives). Independently from species (cattle, sheep, goats) number of stock units is low: the modal class is 0 - 5 stock units. Products are mainly for self-consumption (78.7\%). Livestock is mainly fed in the forest $(27.2 \%)$ or fed with a mixed regime (fodder and grazing in forest (42.6\%). Replies on occupancy of forest by local residents were bivalent, balanced ones: benefic for $41.7 \%$, detrimental for $39.3 \%$, no opinion for $19 \%$.

Heating and cooking is mainly based on LPG (89.7\%), followed by wood (76.7\%) and electricity (27\%). Wood is mainly harvested (illegally too) in the forest $(71.7 \%)$ or purchased (19.3\%). A large majority of respondents (88\%) complains about scarce effort by Forest Administration in providing them with firewood. Domestic garbage is destroyed on site, arguably by fire $(51.7 \%)$, abandoned in the forest (50\%) and thrown into landfills $9.3 \%$.

Illegal wood cutting and illegal constructions are considered important by $11.3 \%$, but of low importance by $60.63 \%$ of respondents. Surprisingly, only $36.7 \%$ of respondents or their families, though living in the forest or rather close to it, are involved in forestry works: cleaning (21.7\%), fire fighting activities (21\%), cork harvesting (21.7)\%. Forest is considered by far an advantage by $87.3 \%$ of respondents. Surveyed people express equivalent opinion about fires trend: increasing (45.7\%). decreasing (45.3\%) constant (only 9\%). A great majority of surveyed people has seen a fire $(90 \%)$, mainly of medium or large size (respectively $43.1 \%$ and $36.3 \%$ ). Their opinion about fire damages mainly refers to crops $(75.7 \%)$, fruit trees $(52.3 \%)$, houses (22.3\%) livestock (20.7\%) and humans (only 2.3\%). About forest fire causes, surveyed people were invited to declare presence or absence of the officially accepted causes, as proposed by Forest Administration. No question involved qualitative evaluation of the phenomenon.

\section{Causes of Forest Fires}

Percentage of causes results as follows:

- Natural: $0.74 \%$

- Accidental: $4.47 \%$

- Voluntary: $52.95 \%$

- Involuntary: $41.79 \%$

Percentages are well consistent with current literature, which often underlines an excess of emphasis given to voluntary fires (Velez, 2000; Franco Irastorza \& Dolz Reus, 2007). The main causes are reported in Table 4 here following (all baladiath merged):

As evident from Tables 4 and 5, a few motives have a fre-
Table 4.

Decreasing frequency of forest fires motives.

\begin{tabular}{cc}
\hline Main motives & $\%$ \\
\hline Pasture renewal & 11.30 \\
Fires set for political reasons (security fires) & 11.24 \\
Cigarette remains & 9.13 \\
Pyromania & 8.67 \\
Agricultural works (burning of cut bush, stubble burning) & 7.03 \\
Illegal garbage dumping and burning & 6.83 \\
Restart of fire & 6.83 \\
Forest works (burning of cut bush) & 6.31 \\
All the others & $<6$ \\
\hline
\end{tabular}

Table 5.

Fire motives in decreasing order of frequency in the three baladiah.

\begin{tabular}{|c|c|c|c|c|c|}
\hline \multicolumn{2}{|l|}{ Ain Zaouia } & \multicolumn{2}{|l|}{ Mizrana } & \multicolumn{2}{|l|}{ Haizer } \\
\hline Motives & (\%) & Motives & (\%) & Motives & (\%) \\
\hline $\begin{array}{l}\text { Fires set for } \\
\text { political reasons }\end{array}$ & 23.29 & Pyromania & 19.63 & $\begin{array}{l}\text { Illegal garbage } \\
\text { dumping and } \\
\text { burning }\end{array}$ & 8.56 \\
\hline Restart of fire & 15.22 & Pasture renewal & $18.06 \mathrm{C}$ & Cigarette remains & s 8.44 \\
\hline $\begin{array}{l}\text { Pasture } \\
\text { renewal }\end{array}$ & 12.73 & Cigarette remains & 15.45 & Pasture renewal & 7.58 \\
\hline $\begin{array}{l}\text { Illegal garbage } \\
\text { dumping and } \\
\text { burning }\end{array}$ & 10.56 & $\begin{array}{l}\text { Fires set for } \\
\text { political reasons }\end{array}$ & 14.40 & Forest works & 7.33 \\
\hline Forest works & 6.21 & Agricultural works & $11.26 \mathrm{C}$ & Children's games & s 6.60 \\
\hline $\begin{array}{l}\text { Agricultural } \\
\text { works }\end{array}$ & 4.66 & $\begin{array}{l}\text { Interest in land use } \\
\text { changes }\end{array}$ & 6.81 & $\begin{array}{l}\text { Agricultural } \\
\text { works }\end{array}$ & 5.99 \\
\hline $\begin{array}{l}\text { Conflict related to } \\
\text { land use }\end{array}$ & 3.42 & $\begin{array}{l}\text { Conflict related to } \\
\text { land use }\end{array}$ & 5.76 & Restart of fire & 5.87 \\
\hline Cigarette remains & 3.42 & Forest works & 4,19 & Pyromania & 5.75 \\
\hline Others & 20.49 & Others & 1.57 & Others & 43.88 \\
\hline
\end{tabular}

quency $>6 \%$, but they strongly differ from a baladiah to another, thus confirming that, at every scale, fire is site and culture specific (Leone et al., 2003).

\section{Factorial Correspondence Analysis}

Given the relevant amount of information gathered by the survey $(300 \times 134)$, forest fires causes were explored also with the help of FCA (Factorial Correspondence Analysis) a technique which belongs to the family of multidimensional descriptive statistics (Maniatis, 2010). We present only significant results of analysis, and some representative scatter plots.

\section{Municipalities, Villages and Causes}

Ain Zaouia is more distant from the average (axes origin), whereas Mizrana and Haizer are symmetrically opposite to it. 
In Ain Zaouia, political fires are the more impressing motive, followed by fire restart; the latter motive, as already reminded, is closely related to security reasons which hamper the efficiency of fire fighting crews, thus confirming a sort of feedback with political fires.

Haizer is characterized by garbage burning, honey gathering, children's games, land use conflicts, followed by less important causes (brash burning, agricultural fires, tourists, machinery, power line arching, vehicle's muffling, hunting conflicts).

Mizrana has its distinctive trait in pastoralism, followed by cigarette remains, pyromania, land use change (it is a municipality rather close to coast, where housing boom is a reality).

Exploding the results in the nine villages, the mentioned matching is:

Ain Zaouia villages:

Ait Amar Moh and Igharbiyene are characterized by political fires and hunting interest, Adbagh by fire restart, conflicts with Administration.

Haizer villages:

Guentour stands out for garbage burning and conflict with Forest Administration, El Mahsar for land use conflicts and forest machinery, Slim for honey gathering and hunting conflicts.

Guentour and El Mahsar appear closer, therefore more similar and more involved with bush burning, whereas Slim is characterized by minor causes, such as machinery, hunting conflicts, land use conflict, agriculture and forest work by machinery.

Mizrana villages:

Mizrana, Tizi Ourabah and Outouba are involved with pastoralism and agricultural fires, in some opposition and rather distant from Azroubar which is characterized by pyromania, interest in land use and cigarette discarding.

For pyromania, present only in this context, probably the term was not well understood by respondents and merely mistaken for unknown as Franco Irastorza \& Dolz Reus (2007) argue.

\section{Location of Villages}

People dwelling villages inside the forest mainly refer to pyromania, but also to cigarette remains, to interest and/or conflicts for land use changes; two main causes dominate: pastoralism, which pertains to their culture and political reasons. People living outside the forest have a less concerned image of problems: they recall rather obvious and banal reasons: children's games, power line arching, tourists, vehicle's mufflers. In a rather intermediate position the replies of people who dwell villages close to the forest or at the edge of it: they mainly refer to forestry works, to restart of fire, to honey gathering, but with strong emphasis on burning of garbage, which is probably part of their familiar scenario.

\section{Educational Level}

Municipalities and level of education form a rather compact cloud, rather distant from two causes which represent outliers: lightning, which is a rare event (within Algeria and all Maghreb) and interest in hunting, which is a forbidden activity now practiced only as poaching, therefore a rather risky one. In order of educational level, illiterate refer to restart of fire, tourists, forestry works, vehicles' mufflers, illegal dumping and burning of domestic waste. Primary and secondary school refer to honey gathering and change of land use. Middle school refers to political reasons and pastoralism and to less important leisure activities, cigarette remains, accident from agriculture and forestry works and machinery.

The University level clearly refers to pastoralism and pyromania, together with power lines arching, interest and conflicts in land use. In such results we can argue that some importance have mass media, since the motives are rather "high" and echo the frequent analysis circulated by them, sometimes containing not acceptable fire cause hypothesis such as glass refraction or magnification (Belgacem, 2012).

In the replies by the University level respondents we cannot also exclude a sort of reactivity in altering their performance, probably to conform to the expectations of the surveyors. At the opposite, the group of illiterate and low education summoned their experience of livelihood and traditional, rural, pastoral culture.

Pastoralism and political fires are quite coincident with axes origin and close to middle age classes, mainly 40 - 49, which in part arguably recalls personal experiences of the black period. Medium age class 30 - 39 seems attracted by land use changes and conflicts. More aged class 50 - 59 and 60 and over, clearly refer to livelihood activities: pastoralism, honey gathering, i.e. the traditional activities of aged rural people.

\section{Age Classes}

Analysis of age classes gives interesting result, though some classes are clustered: 30 - 39, 50 - 59, 60 and over are tightly grouped close to the origin of axes but under A1, whereas 20 29 and 40 - 49 are over the axe but symmetrically distant from axe A2. Rather distant from the cluster stays the younger class, $>20$, which appears as an outlier. Younger respondents refer to leisure activities, as expected; aged 20 - 29 are closer to pyromania, rather close to garbage dumping and cigarette remains, arguably under the influence of mass media.

\section{Scatter Plots}

Examples of scatter plots issued from FCA are here following (Figures 2 and 3).

\section{Discussion}

Survey results about causes are commented in their order of importance as in Table 5 but only when exceeding a frequency of $4 \%$. By far the most serious cause of forest fires attributed to the rural population is deliberate burning for grazing and land improvement.

\section{The Most Relevant Motivations}

Pastoralism: Pastoral fires are a traditional practice all over the Mediterranean basin in areas where fire is the cheapest way to regenerate pastures invaded by shrub (Cemagref, 2004; Pyne, 1997). Range burning could be related to the high number of sheep in the country as a whole: in Algeria (with more than 25 millions livestock, $77 \%$ of which represented by sheep; FAO, 2012) demand for red meat is high and growing. In the ' 90 s the country imported around 20\% of all that it uses (Homewood, 1993). Now sheep meat represents $30 \%$ of the total meat production of Algeria (Dutilly-Diane, 2006). In general fire is not 


\section{O. MEDDOUR-SAHAR ET AL.}

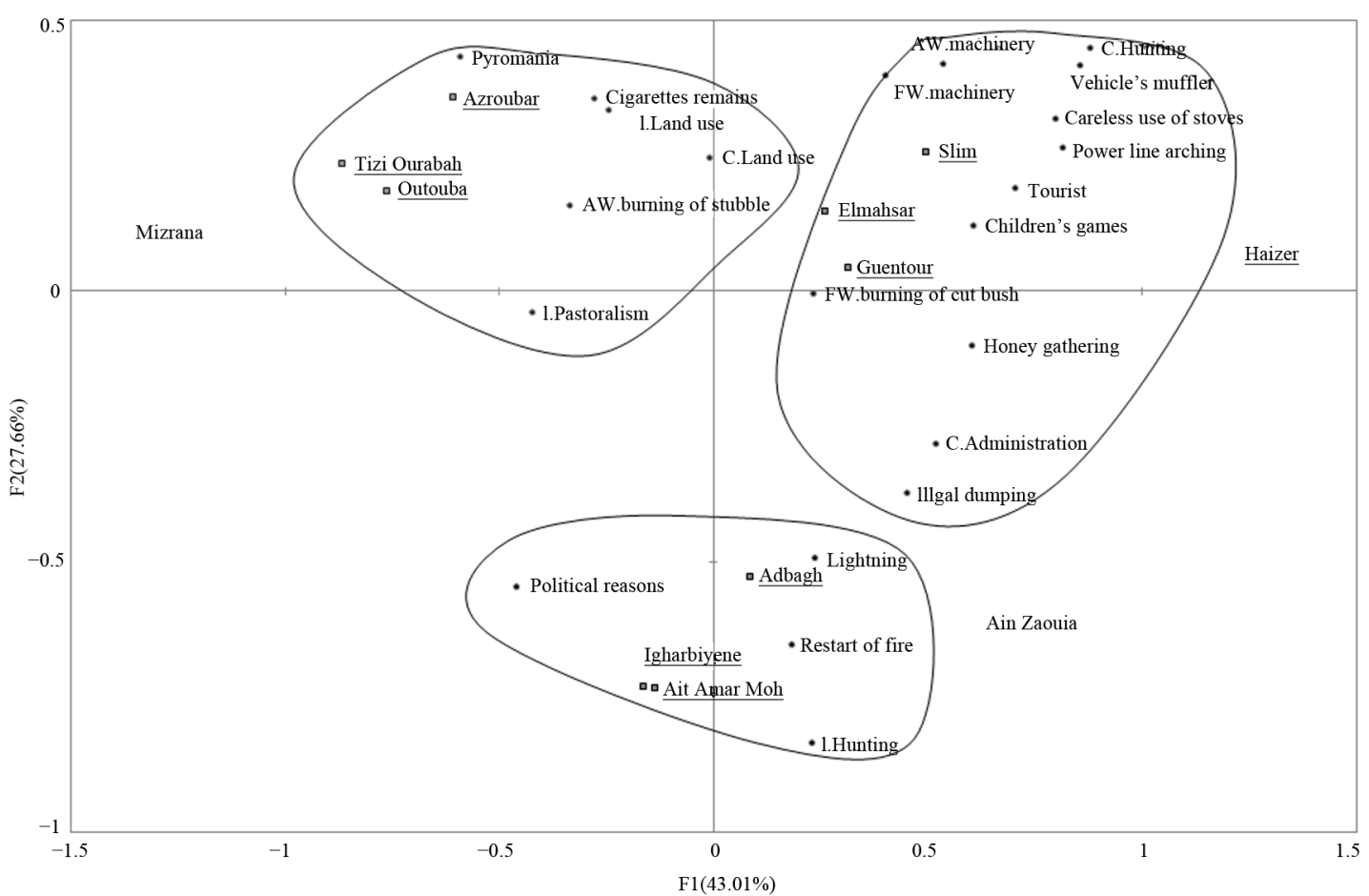

Figure 2.

FCA scatter plot related to the nine villages and causes. A1 axe explains $43 \%$ of variance, A2 explains $28 \%$.Correspondence of motivation with municipalities is rather evident.

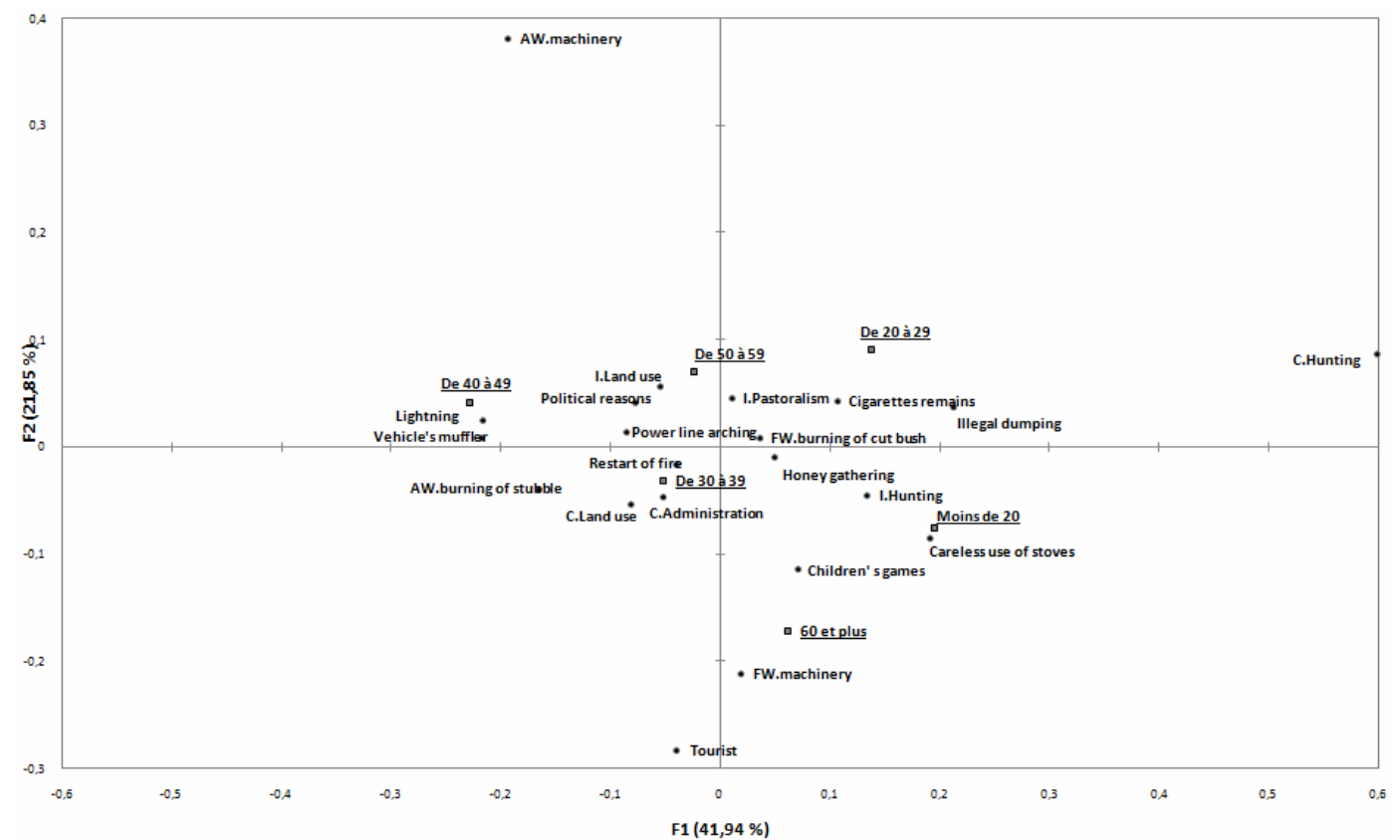

Figure 3.

FCA scatter plot related to age classes of surveyed and causes. A1 axe explains $37 \%$ of variance, A2 explains $27 \%$.

directly applied to the forests, but rather to marginal rangelands and shrub lands close to them. When vegetation is stressed after a long summer drought, easily fires get out of hand affecting the forest boundary (Meddour \& Derridj, 2012).The tendency to increase range areas at the detriment of degraded forest cover is a real problem, observed in other Mediterranean countries (e.g. in Sardinia, Italy). Shepherds do not refrain from use of fire, even if this means risk for forests (Meddour-Sahar et al., 2012). Fire setting normally follows traditional rules, such us procedures, timing, and time of return on same site; therefore this practice could be defined as a cultural trait of the local populations. 
Political fires are the most site specific and disquieting cause of wildfires for Algeria, mainly in Kabylia. The term refers to forest fires as a tool used by the State in its fight against jihadi combatants (UNHCR, 2001; Dridi, 2002; Kervin \& Gèze, 2004; Rahal, 2012). During the Algerian war (1954-1962) the French Army is reported having burned about $70 \%$ of forest in the Massif of Bou-Taleb (Madoui, 2000, 2002) also using napalm to destroy insurgents in Movis forest (Ouarsenis forests; Sari, 1976). Burned forests in Oued Lardjem, Theniet el Had, Ain Antar still exhibit scars of burning by napalm.

Cigarette remains: Carelessly tossed cigarette butts are responsible of roadside fires. Cigarettes, under normal conditions, do not start wild land fires unless the relative humidity is under $22 \%$, it is windy, and a continuous, cured, finely-particulated fuel-bed exists (NWCG, 2005). Lack of roadside maintenance (through slashing or manual brush removal) increases fire hazard in summer, since roadsides are recognized as critical ignition start points (Romero-Calcerrada et al., 2008; Chapman \& Balmain, 2004; Cardille et al., 2001) No specific roadside treatments (such as fire safety strips along roads i.e. "anti-cigarette strip"; FAO, 2001) to prevent the occurrence of fires and minimize the danger of fire spread are actually required for roads crossing forests or plantations in the area (Meddour-Sahar \& Derridj, 2010).

Pyromania results with high frequency in general, and rather high, first best, in the baladiah of Mizrana. The term is often improperly used as a synonym of arsonist (Instituto Medio Ambiente, 2003; Dolz Reus \& Franco Irastorza, 2005; Lovreglio et al., 2010), or just an improper way to express "unknown” (Franco Irastorza \& Dolz Reus, 2007). In a recent survey in Sardinia, carried out by Delphi technique, pyromania resulted among the main causes of fires in the province of Cagliari (Lovreglio, unpublished data). It is probable that the number of authentic pyromaniacs, who suffer an addictive behavior, is over-estimated as many fire-raisers if caught "red handed" claim to be suffering from mental trauma in an attempt to escape a custodial sentence (Ashby, 2012).

Agricultural works refers to burning of cut bush or stubble burning, i.e. traditional systematic burning of stubble, for the preparation of the agricultural land for new sowing-purposes and the elimination of residues that restrict exploitation. Forest works are a rather common case of negligence, quite often related to old age of responsible, or imprudence; more rarely related to an overconfidence and boldness in manipulating fire.

Restart of fire can be caused by fire-fighters who do not ensure that the fire is completely out; the alarming conditions of insecurity in Kabylia, where terroristic groups are reported still active, could justify this apparently negligent behavior. Another reason could be the high number of fires which the fire crews must intervene on, therefore having no time enough for mopping-up any fire after it has been controlled (Meddour-Sahar et al., 2012).

Garbage burning is a direct consequence of extreme population density and type of settlements, which make garbage collecting rather difficult. The production of domestic waste in Algeria is estimated in 657,000 tons/year; (Benouar, n.d.), i.e. $0.50 \mathrm{Kg} / \mathrm{hab} / \mathrm{day}$ (Dorbane, 2007). In the town of Tizi Ouzou the daily amount of domestic waste is estimated about 68.38 tons, corresponding to $0.81 \mathrm{~kg} / \mathrm{hab}$./day. In the wilaya of Tizi Ouzou a proliferation of illegal, uncontrolled dumps along roadside is reported, with the presence of only 30 controlled garbage dumping sites v. 1236 illegal ones (Meddour-Sahar \&
Derridj, 2010; DPAT, 2011), i.e. an average of 18 sites per municipality. Dump sites are preferential points of fire start in forests (Djema \& Messaoudene, 2009)

Interest in land use change mainly refers to fire used to change land use: from forested area to agricultural area or, more frequently, to building area. The latter is more evident in Mizrana, where demand of space for urbanization is very high. Such changes have no relevant obstacles given the lack of Land Cadastre and negligible fines for illegal behaviors. An increasing demand for housing can induce forest fires as an illegal means to increase the supply of available land (Gonzalez, 2007).

Children's games (with lighters, matches, small fireworks such as firecrackers or small amount of explosives) are currently reported in all countries, not therefore having any local character. Children cause fires out of curiosity or mischief; in the study area, fire is more probably a possible occasion to spend time together and relieve boredom, lacking other opportunities for free time.

Other fire causes exhibiting a frequency $<4 \%$ are just listed, without a commentary: Tourists (3.09\%), Honey gathering and related use of smoke (2.83\%), Vehicle's muffler $(2.76 \%)$, Barbecue fires (2.04\%), Power line arching (1.71\%), Conflicts with Administration (1.31\%), Hunting conflicts (0.85\%), Interest in hunting (1.25\%), Lightning (0.79\%).

Just some comments for conflicts with Foresters and Forest Administration seem useful. Conflicts related to forest policy could be interpreted as a kind of reaction, for example, when reforestation is carried out at the expense of traditional extensive grazing lands, against the lack of negotiation with the population (Meddour-Sahar et al., 2012). Similar reactions by local populations against national programs of reforestation (the so called Green Belt of the '70s) were already reported (Vallejo, 2005).

Conflicts with foresters. The policy adopted by the Forest. Administration often tends to further marginalize rural populations, which manifest themselves in the firing of forests against the application of a criminal jurisdiction and a colonial-style behaviour (Berchiche, n.d.). In those cases, though limited in frequency, fire can have a subtle but strong symbolism, because a patch of fire is a very visible and powerful claim.

Rural incendiarism is an expressive form of resistance, allowing a powerful statement to be expressed, with some livelyhood benefits through freshly cleared land or regenerated pasture, while having fewer constraints than other forms of protest because of its anonymity and difficulty to be identified (Holmes, 2007).

\section{Causes Classification}

For a classification of voluntary fires we adopted the classification by Douglas et al., (1992), which proposes six possible motives for arson: Vandalism, Excitement, Revenge or Protest, Crime Concealment, Profit, and Extremist. Douglas' classification was mainly conceived for urban fires but it well fits also with wild land fires (Leone \& Lovreglio, 2003).

In the study case, ten possible motives after Douglas can be retrieved: Extremist: for political fires; Revenge or protest: for conflict related to land use, conflicts with foresters and Administration, hunting conflicts; Profit: for interest in land use and change in land use, for pastoral fires, for illegal garbage burning, for hunting. 
For all the others, mainly involuntary fires, excluding pyromania classified as a mental addictive disorder (APA, 2000) a possible unifying category is folk crime (Bankston \& Jenkins, 1982). Many law violations in rural communities such as the violation of gambling, hunting and game laws, and woods burning fall in such category. Woods burning, like poaching, is deeply rooted in some rural cultures (Bankston \& Jenkins, 1982; Forsyth \& Marckese, 1993; Forsyth et al., 1998).

As a result these violations became accepted as normal behavior in some cultural settings. Setting fire on woods is a "...custom (emphasis added by Authors) that has been predicated upon the assumption that timber is either an undesirable barrier to land use or, at best, an expendable commodity secondary in importance to other land uses. In the course of time...it has become accepted as normal behavior... Although fire setters may be few in number, they can practice fire setting with the assurance or at least the toleration of their activities because community members subscribe in some degree the beliefs and/or attitudes that motivate the fire setter" (Bertrand \& Baird, 1975: pp. 6 and 11).

All this explained, behind the majority of motives for setting fire on woods in Kabylia some subsistence reasons exist (Emery \& Pierce, 2005). Of course, the Penal Code of Algeria (Grim, 1989), is rather severe with fire setters, who are sentenced to hard labour jobs.

\section{Conclusion and Final Remarks}

Survey carried out in the three representative municipalities had the main scope to uncover motivations and drivers that lie behind wildfire in Kabylia. Of course we describe causes as perceived by local inhabitants and not by professionals of Forest Administration, since their statistics admit that the totality of fires is of unknown origin (99\% in Tizi Ouzou wilaya).

We decided to give voice to the inhabitants, therefore admit- ting and accepting that their responses are frank and truthful. Our results therefore concern truth-as-observed, not exact science (Jollands et al., 2011).

It is the first time that a similar survey is carried out in Algeria; at our knowledge, this procedure is not so common also in more advanced countries, where statistic are always compiled on the basis of the subjective knowledge of professionals charged of this task. The fire scenario of our survey depicts relationship among people, land and fire rather different from the rhetoric image reported in some classical books on forest fires in Algeria, for instance Gravius (1866) and Thibault (1866).

In our results forested areas are degraded by human overuse and impact, swarming with a myriad of people using fire in a more or less legal way. The forest is a place where to use fire for getting fodder to animals; to illegally extract stones, accelerating the operations by burning used tires; to use fire to relieve boredom; to dispose garbage and wastes and burning them: in short, gradually consuming the forest or eroding it.

Results highlight a complex reality, issued from a new style of life where people live in the backcountry but work (if they do so..) in towns and are therefore in some way obliged to find new ways of problems solving, where time saving is an imperative, and fire is the privileged tool.

We can synthesize as follows: the causes, as perceived by dwellers (we insist that they are perceived but not real) can be distinguished in a "common core", represented by a cluster of negligent behaviors and scarcely important folk crimes; two more evident causes, represented by political fires and pastoralism, clearly dominate on them, whichever the criterion of analysis.

The negligent behaviors recall the anarchistic activities practiced in the Algerian forests (Djema \& Messaoudene, 2009), results of the release of the rules of a former rural culture based on traditional behaviors, now no more consistent with changed style of life and age and/or education contrasts.

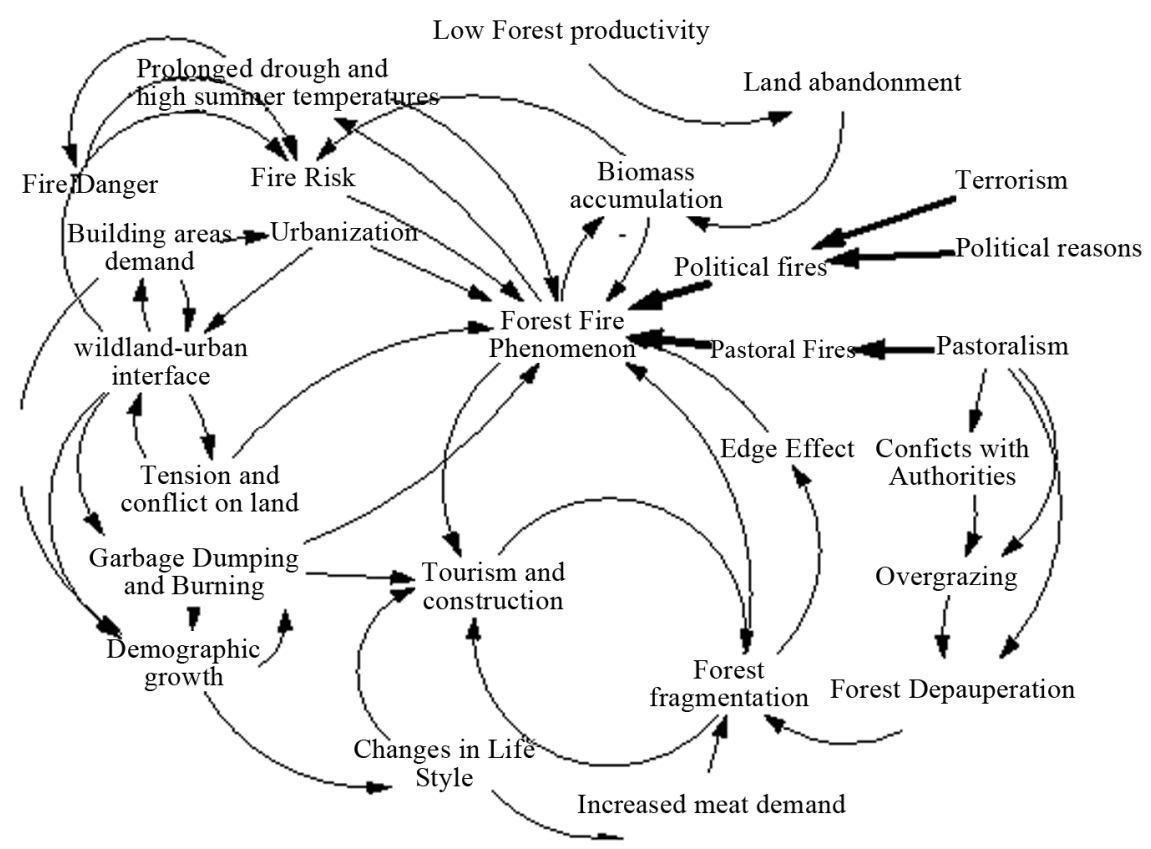

Figure 4.

CLD of forest fires and causative agents (factors) for Kabylia and Algeria: the number of arrows visualizes the multiplicity and complexity of interrelated factors. 
We propose here as a conclusion (Figure 4) a CLD (Causal Loop Diagram; Richardson \& Pugh, 1981; Kim, 1992), to visualize relationships of the most important variables which are behind causes in Algeria and in Kabylia. ${ }^{2}$

Though related to only three municipalities (i.e. $2.67 \%$ of the 67 municipalities of Tizi Ouzou and 45 municipalities of Bouira; $0.0019 \%$ of the 1541 municipalities of Algeria), our result is well representative of Kabylia.

We underline the importance of our survey, which for the first time measured the unknown causes, accounting for $99 \%$ in official statistics. Their importance must be considered in the scope of a new approach to fire fighting: from fire suppression, mainly oriented to emergency measures, therefore a "reactive" process, to a longer term policy of removing the structural causes (Birot, 2009; Velez, 2008), then a more "pro-active” approach.

But if wildfires are to be tackled conclusively, then there is a need (Jollands et al., 2011) to address the root causes which lead to fire setting, properly targeting the social groups and concentrating efforts consistently with fire risks.

\section{Contribution}

All authors contributed extensively to the work presented in this paper. O.M.S designed the study, collected and analyzed data; O.M.S. and V.L. wrote the manuscript; R.M., R.L., A.D. gave technical support and conceptual advice. All authors discussed the results and implications and commented on the manuscript at all stages.

\section{REFERENCES}

American Psychiatric Association (2000). Diagnostic and statistical manual of mental disorders (4th ed.). Washington DC: Author.

Ashby, P. (2012). Spain’s burning forests-fire-raising and pyromania. URL (last checked 6 June 2012).

http://suite101.com/article/spains-burning-forests-fire-raising-and-py romania-a405886

Bankston, W. B., \& Jenkins, Q. A. L. (1982). Rural crime in the south: An overview of research traditions and theoretical issues. The Rural Sociologist, 2, 233-241.

Baskaran, K. D., Bariteau, M., El-Kassaby, Y. A., Huoran, W., Kagayama, P., Kigomo, B. N., Mesén, F., Midgley, S., Nikiema, A., Patiño, V. F., Prado, J. A., Sharma, M. K., \& Ståhl, P. H. (2002). Regional updates, prepared for the twelfth session of the FAO panel of experts on forest gene resources, Rome, Italy, 21-23 November 2001. Forest Genetic Resources Working Papers, Working Paper FGR/34E. Rome: Forest Resources Development Service, Forest Resources Division. URL (last checked 4 June 2012).

http://www.fao.org/DOCREP/005/AC646E/ac646e09.htm

Belgacem, D. (2012). Le DG de la Protection Civile à "Liberté" "nous avons engagé 15,000 hommes pour lutter contre les feux de forêt". URL (last checked 15 September 2012).

http://www.liberte-algerie.com/actualite/nous-avons-engage-15-000h ommes-pour-lutter-contre-les-feux-de-foret-le-dg-de-la-protection-ci vile-a-liberte-184288

Benouar, D. (n.d.). The need for an integrated disaster risk reduction management strategy in North African cities: A case study of urban vulnerability in Algiers (Algeria). URL (last checked 1 June 2012). http://acds.co.za/uploads/jamba/vol1no1/benouer.pdf

Bensaid, S., Gasmi, A., \& Benhafied, I. (2006). Les forêts d'algérie de Césarée la romaine a ce jour. Forêt méditerranéenne, 3, 267-274. URL (last checked 1 February 2012).

${ }^{2}$ A causal loop diagram consists of variables connected by arrows, denoting the causal influences among the variables. Diagram was drawn using Vensim plus software (www.vensim.com/software.html). www.foret-mediterraneenne.org/fr/catalogue

Berchiche, T. (n .d.). La politique forestière et le développement rural (ronéotypé).

Bertrand, A. L., \& Baird, A. W. (1975). Incendiarism in southern forests: A decade of sociological research. Washington DC: United States Department of Agriculture.

Birot, Y. (2009). Living with wildfires: What science can tell us. EFI Discussion 15, European Forest Institute.

Boudy, P. (1952). Guide du forestier en Afrique du nord. Paris: La Maison Rustique.

Cardille, J. A., Stephen, J., Ventura, S. J., \& Turner, M. G. (2001). Environmental and social factors influencing wildfires in the upper midwest, United States. Ecological Applications, 11, 111-127.

CEMAGREF (2004). Haute-corse, pastoralisme et incendie. Info DFCI, Bulletin du Centre de Documentation Forêt Méditerranéenne et Incendie, 52, 1-8. URL (last checked 2 June 2012).

http://www.irstea.fr/

CEMAGREF (2009). Repeated fire and drought: A menace for Mediterranean forests. Science Daily, 26.

Chapman, S., \& Balmain, A. (2004). Reduced-ignition propensity cigarettes. A review of policy relevant information. Commonwealth Department of Health and Ageing. URL (last checked 1 June 2012). http://www.health.gov.au/internet/main/publishing.nsf/Content/1526 AD854C903649CA256F8E0011ACBE/\$File/smoking_rip.pdf

Clément, V. (2005). Les feux de forêt en Méditerranée: Un faux procès contre Nature. L'Espace Géographique, 4, 289-304.

Colin, P. Y., \& Jappiot, M. (2001). Politiques de prévention et de réhabilitation en réponse aux origines des incendies de forêt. Exemple de quatre pays du bassin méditerranéen (Chypre, Maroc, Syrie, Tunisie). Info DFCI, Bulletin du Centre de Documentation Forêt Méditerranéenne et Incendie, 47, 1-5. URL (last checked 2 June 2012). http://www.irstea.fr/

Davis, D. K. (2004). Eco-governance in French Algeria: Environmental history, policy and colonial administration. Proceedings of the Western Society for French History, 32, 328-345.

Direction Planification Aménagement Territoire (DPAT) (2011). Annuaire statistique de la wilaya de Tizi Ouzou, 2010. No. 27.

Djema, A., \& Messaoudene, M. (2009). The Algerian forest: Current situation and prospect. In M. Palahi, Y. Birot, F. Bravo, \& E. Gorrize (Eds.) Managing Mediterranean forest ecosystems for non-timber goods and services (pp. 17-28). EFI Proceedings No 57.

Dolz Reuss, M. L. (2005). State of the art of forest fire causes in Spain. Proceedings of the II International Conference on Prevention Strategies of Fires in Southern Europe, Barcelona, 9-11 May 2005.

Dorbane, N. (2007). Contraintes de la gestion des déchets dans les villes algériennes: Cas de Tizi-Ouzou. Revue Campus, 6, 4-16.

Douglas, J. E., Burgess, A. W., Burgess, A. G., \& Ressler, R. K. (1992). Crime classification manual. New York: Lexington Books.

Dridi, D. (2002). The army: Friends of the scorched earth. URL (last checked 6 June 2012).

http://www.algeria-watch.org/en/articles/2002/bainem.htm

Dutilly-Diane, C. (2006). Review of the literature on pastoral economics and marketing: North Africa report prepared for the world initiative for sustainable pastoralism. IUCNEARO. URL (last checked 6 June 2012).

http://data.iucn.org/wisp/documents_english/north_africa_reports.pdf

Emery, M. R., \& Pierce, A. R. (2005). Interrupting the "telos": Locating subsistence in contemporary US forests. Environment and Planning A, 37, 981-993. doi:10.1068/a36263

FAO (2001). International handbook on forest fire protection. Technical guide for the countries of the Mediterranean basin.

FAO (2010). Forests and climate change in the near east region. Forests and climate change. Working Paper 9.

FAO (2012). State of Mediterranean Forests (SoMF). URL (last checked 5 April 2012).

http://www.fao.org/forestry/225560f888476830f6931aba4b886baea8 8af1.pdf

Forsyth, C. J., \& Marckese, T. A. (1993). Folk outlaws: Vocabularies of motives. International Review of Modern Sociology, 23, 17-31.

Forsyth, C. J., Gramling, R., \& Wooddell, G. (1998). The game of 
poaching: Folk crimes in southwest Louisiana. Society and Natural Resources, 11, 25-38. doi:10.1080/08941929809381059

Franco Irastorza, I., \& Dolz Reus, M. L. (2007). Análisis de la percepción de la sociedad ante el problema de los incendios forestales: Metodología y resultados. Actas de la IV Conferencia Internacional sobre Incendios Forestales, Sevilla, 13-18 May 2007.

García Ortega, E., Trobajo, M. T., López, L., \& Sánchez, J. L. (2011). Synoptic patterns associated with wildfires caused by lightning in Castile and Leon, Spain. Natural Hazards and Earth System Sciences, 11, 851-863. doi:10.5194/nhess-11-851-2011

Gonzalez, A. (2007). Libertad, the housing boom and forest fires. URL (last checked 16 May 2012). http://ssrn.com/abstract=1107120

Gravius, G. (1866). Les incendies de forêt en Algérie leurs causes vraies et leurs remèdes. Constantine: Chez Louis Marie librairie Paris.

Grim, S. (1989). Préaménagement et protection des forêts contre l'incendie. Belgique: Le préaménagement forestier. Ministère de l'Hydraulique d'Algérie \& Unité des Eaux et Forêts de l'Université catholique de Louvain-la-Neuve, 271-289.

Harris, S. A. (2007). Colonial forestry and environmental history: British policies in Cyprus, 1878-1960. Ph.D. Dissertation, Austin: Graduate School of the University of Texas. URL (last checked 16 April 2012).

http:// repositories.lib.utexas.edu/bitstream/handle/2152/3244/harris

Holmes, G. (2007). Protection, politics and protest: Understanding resistance to conservation. Conservation \& Society, 2, 184-201.

Homewood, K. M. (1993). Livestock economy and ecology in El Kala, Algeria. Evaluating ecological and economic costs and benefits in pastoralist systems. Pastoral Development Network Papers 35a. URL (last checked 1 April 2012).

http://www.odi.org.uk/resources/details.asp?id=4467\&title=social-ec onomic-ecological-cost-benefit-analysis-pastoralism

IIA (1933). Enquête internationale sur les incendies de forêts. Rome: Institute International d'Agriculture.

Instituto de Estudios del Medio (2003). Estudio sociòlogico sobre la perceptión de la poblacion Española hacia los incendios forestales. Associatión para la Promocciòn de Actividades Socioculturales. URL (last checked 10 April 2012).

http://www.idem21.com/descargas/pdfs/IncendiosForestales.pdf

Jollands, M., Morris, J., \& Moffat, A. J. (2011). Wildfires in Wales. Farnham: Forestry Commission Wales. URL (last checked 16 June 2012).

http://www.forestry.gov.uk/fr/wildfiresinwales\#finalreport

JRC (2010). Forest fires in Europe 2010. Report No. 11. EUR-Scientific and Technical Research, 1831-9424. URL (last checked 16 March 2012).

http://effis.jrc.ec.europa.eu/reports/fire-reports

Kervyn, J., \& Gèze, F. (2004). The organization of the forces of pressure. Justice Commission for Algeria at the 32nd Session of the Permanent Peoples' Tribunal on Human Rights Violations in Algeria (1992-2004). URL (last checked 16 April 2012).

http://www.algeria-watch.org/pdf/pdf_en/forces_repressure.pdf

Kim, D. H. (1992). Toolbox: Guidelines for drawing causal loop diagrams. The Systems Thinker, 3, 5-6

Leone, V., \& Lovreglio, R. (2003). Human fire causes: A challenge for modeling. In E. Chuvieco, M. Pilar Martín, \& C. Justice (Eds.), Innovative concepts and methods in fire danger estimation 4th international workshop on remote sensing and GIS applications (pp. 89-98). Ghent, 5-7 July 2003.

Leones, J. (1998). A guide to designing and conducting visitor surveys. URL (last checked 6 May 2012).

http://ag.arizona.edu/pubs/marketing/az1056/az1056.html

Leone, V., Lovreglio, L., Pilar Martín, M., Martínez, J., \& Vilar, L. (2009). Chapter 11 human factors of fire occurrence in the Mediterranean. In E. Chuvieco (Ed.), Earth observation of wildland fires in Mediterranean ecosystems (pp. 149-170). Berlin, Heidelberg: Springer-Verlag.

Lovreglio, R., Marciano, A., Patrone, A., \& Leone, V. (2012). Le motivazioni degli incendi boschivi in Italia: Risultati preliminari di un'indagine pilota nelle Province a maggiore incidenza di incendi. Forest@, 9, 137-147. URL (last checked 26 June 2012). http://www.sisef.it/forest@/contents/?id=efor0693-009 doi:10.3832/efor0693-009

Madoui, A. (2000). Forest fires in Algeria and the case of the domanial forest of Bou-Taleb. International Forest Fire News, 22, 9-15.

Madoui, A. (2002). Les incendies de forêt en Algérie. Historique, bilan et analyse. Forêt Méditerranéenne, 1, 23-30. URL (last checked 1 February 2012). www.foret-mediterraneenne.org/fr/catalogue

Maniatis, P. (2010). Greek census 1981. A case of factorial corresponddence analysis. International Research Journal of Finance and Economics, 35, 99-111.

Marc, P. (1916). Les incendies de forêt en Algérie. Notes sur les forêts de l'Algérie. Alger: Typographie Adolphe Jourdan. Imprimeur libraire-Editeur.

Meddour-Sahar, O. (2008). Contribution à l'étude des feux de forêts en Algérie: Approche statistique exploratoire et socio-économique dans la wilaya de Tizi Ouzou. Thèse de Magister, Alger: INA El Harrach.

Meddour-Sahar, O., \& Derridj, A. (2010). Le risque d'incendie de forêt, évaluation et cartographie (Wilaya de Tizi Ouzou, période 19862005). Sécheresse, 21, 187-195.

Meddour-Sahar, O., \& Derridj, A. (2012). Bilan des feux de forêts en Algérie: Analyse spatiotemporelle et cartographie du risque (période 1985-2010). Sécheresse, 23, 133-141.

Meddour-Sahar, O., Meddour, R., \& Derridj, A. (2008). Les causes des incendies de forêt en Algérie. Technologie et Environnement. URL (last checked 1 February 2012).

www.recy.net/actualites/20080615-incendies-algerie

Meddour-Sahar, O., Meddour, R., Leone, V., Lovreglio, R., \& Derridj, A. (2012). Analysis of forest fires causes and their motivations in north Algeria: The Delphi technique. iForest-Biogeosciences and Forestry (accepted).

NWCG (2005). Wildfire origin \& cause determination handbook 1. URL (last checked 23 April 2012). http://www.nwcg.gov/pms/pubs/pubs.htm

Petersen, W. A., \& Rutledge, S. A., (1998). On the relationships between cloud-to-ground lightning and convective rainfall. Journal of Geophysical Research, 103, 14025-14040. doi:10.1029/97JD02064

Pyne, S. (1997). Vestal fire: An environmental history, told through fire, of Europe and Europe's encounter with the world. Seattle and London: University of Washington Press.

Rahal, M. (2012). Fused together and torn apart stories and violence in contemporary Algeria. History \& Memory, 24, 118-151. doi:10.2979/histmemo.24.1.118

Richardson, G. P., \& Pugh III, A. L. (1981). Introduction to system dynamics modeling with DYNAMO. Cambridge MA: Productivity Press.

Romero Calcerrada, R., Novillo, C. J., Millington, J. D. A., \& Gómez Jiménez, I. (2008). GIS analysis of spatial patterns of human-caused wildfire ignition risk in the SW of Madrid (central Spain). Landscape Ecology, 23, 341-354. doi:10.1007/s10980-008-9190-2

Sari, D. (1976). L'homme et l'érosion dans l'Ouarsenis (Algérie). Alger: Editions SNED.

Secretariat of the Convention on Biological Diversity (2001). Impacts of human-caused fires on biodiversity and ecosystem functioning, and their causes in tropical, temperate and boreal forest biomes. CBD Technical Series No. 5, Montreal: SCBD.

Thibault, R. (1866). Des incendies de forêt en Algérie: De leurs causes et des moyens préventifs et défensifs à leur opposer. Constantine: V Guende Librairie, Place du Palais, Paris: E. Galette Librairie.

Thirgood, J. (1981). Man and the Mediterranean forest: A history of resource depletion. New York: Academic Press.

UNHCR Algeria (2001). Country report UNHCR/ACCORD. 7th European Country of Origin Information Seminar, Berlin, 11-12 June 2001.

Vallejo, R. (2005). Chapter 45 Restoring Mediterranean forests. In S. Mansourian, D. Vallauri, \& N. Dudley (Eds.), Forest restoration in landscapes: Beyond planting trees (pp. 313-319). New York: Springer. URL (last checked 8 April 2012). http://www.bf.unilj.si/fileadmin/groups/2716/downloads/\%C4\%8Cla nki_vaje/2.VS\%C5\%A0/Mansurian_Forest_restoration_landscapes.p df 


\section{O. MEDDOUR-SAHAR ET AL.}

Vélez, R. (1991). Los incendios forestales y la politica forestal. Revista de Estudios Agro-Sociales, 158, 83-104.

Vélez, R. (2000). La defensa contra incendios forestales: Fundamentos y experiencias. Madrid: McGraw Hill.

Vélez, R. (2008). Europe: Development and fire. Proceedings of the Second International Symposium on Fire Economics, Planning, and
Policy: A Global View. Pacific Southwest Research Station General Technical Report, US Department of Agriculture, Forest Service.

WWF-IUCN (2007). Forest fires in the Mediterranean. URL (last checked 4 May 2012)

http://www.uicnmed.org/web2007/documentos/Background_med_fo rest_fires.pdf 